\title{
Effect of Hydrogen Content in Intrinsic a-Si:H on Performances of Heterojunction Solar Cells
}

\author{
Yun-Shao Cho, ${ }^{1}$ Chia-Hsun Hsu, ${ }^{2}$ Shui-Yang Lien, ${ }^{3}$ Dong-Sing Wuu, ${ }^{1}$ and In-Cha Hsieh ${ }^{2}$ \\ ${ }^{1}$ Department of Materials Science and Engineering, National Chung Hsing University, Taichung 402, Taiwan \\ ${ }^{2}$ Graduate Institute of Precision Engineering, National Chung Hsing University, Taichung 402, Taiwan \\ ${ }^{3}$ Department of Materials Science and Engineering, DaYeh University, ChungHua 51591, Taiwan
}

Correspondence should be addressed to Shui-Yang Lien; syl@mail.dyu.edu.tw

Received 14 June 2013; Accepted 9 August 2013

Academic Editor: Gaetano Di Marco

Copyright (C) 2013 Yun-Shao Cho et al. This is an open access article distributed under the Creative Commons Attribution License, which permits unrestricted use, distribution, and reproduction in any medium, provided the original work is properly cited.

\begin{abstract}
Influences of hydrogen content in intrinsic hydrogenated amorphous silicon (i-a-Si:H) on performances of heterojunction (HJ) solar cells are investigated. The simulation result shows that in the range of $0-18 \%$ of the i-layer hydrogen content, solar cells with higher i-layer hydrogen content can have higher degree of dangling bond passivation on single crystalline silicon (c-Si) surface. In addition, the experimental result shows that $\mathrm{HJ}$ solar cells with a low hydrogen content have a poor a-Si:H/c-Si interface. The deteriorate interface is assumed to be attributed to (i) voids created by insufficiently passivated c-Si surface dangling bonds, (ii) voids formed by $\mathrm{SiH}_{2}$ clusters, and (iii) $\mathrm{Si}$ particles caused by gas phase particle formation in silane plasma. The proposed assumption is well supported and explained from the plasma point of view using optical emission spectroscopy.
\end{abstract}

\section{Introduction}

The hydrogenated amorphous silicon/crystalline silicon (a$\mathrm{Si}: \mathrm{H} / \mathrm{c}-\mathrm{Si}$ ) heterojunction (HJ) solar cell is one of the most interesting technological solutions for the photovoltaic market owing to its excellent performance and also its low processing costs. Some groups have already reported encouraging results for silicon $\mathrm{HJ}$ cells with a-Si:H emitters deposited by plasma-enhanced chemical vapor deposition (PECVD) [1]. Recently, efficiencies of up to $23 \%$ using PECVD have been demonstrated $[2,3]$. In $\mathrm{HJ}$ solar cells, the control of the interface between different materials is an important factor for high-cell performances. Particularly, the reduction of carrier recombination at the $\mathrm{p} / \mathrm{n}$ interface is critical. Extensive studies have also demonstrated that the use of a very thin intrinsic (i-) a-Si:H buffer layer inserted at the interface can minimize the interface recombination and thus increase the efficiency of $\mathrm{HJ}$ solar cells [4-6].

In $\mathrm{i}-\mathrm{a}-\mathrm{Si} \mathrm{H}$ deposition, process parameters should be carefully controlled since they determine the film properties. It is found that lowering the deposition temperature tended to raise $\mathrm{Si}-\mathrm{H}_{2}$ bond concentration and thus lowering the dangling bond passivation quality [7]. High temperature can somewhat lead to partial epitaxial Si growth which contains more defects than amorphous films [8,9]. Moreover, hydrogen dilution is usually adopted for lowering electron temperature and suppressing poly silane radicals $[10,11]$. A moderate dilution ratio is reported to result in a longer effective lifetime of $\mathrm{Si}$ wafer [12]. However, the effects of ilayer hydrogen content and plasma status on performances of $\mathrm{HJ}$ solar cells are rarely reported.

In this study, the i-layer hydrogen content effect is investigated by computational simulation. Then, we practically fabricate $156 \times 156 \mathrm{~mm}^{2}$ large-size HJ solar cells with highand low-hydrogen content to validate the simulation result. Furthermore, the interface quality between i-layer and c-Si in high- and low-hydrogen content cases is discussed from the plasma emission spectra point of view.

\section{Experimental}

The two-dimensional, commercially available software Silvaco technology computer aided design (TCAD), from Silvaco Inc., was used to solve the Poisson equation coupled with the continuity equations of electrons and holes for virtual devices by dividing the whole structure into finite elements. 
TABLE 1: TCAD input parameters for $\mathrm{n}-\mathrm{Si} / \mathrm{i}-\mathrm{Si} / \mathrm{c}-\mathrm{Si} \mathrm{HJ}$ solar cells with various hydrogen content of i-layer.

\begin{tabular}{|c|c|c|c|c|}
\hline Device parameters & \multicolumn{4}{|c|}{ Value } \\
\hline Device area $\left(\mathrm{cm}^{2}\right)$ & \multicolumn{4}{|c|}{1} \\
\hline Front surface & \multicolumn{4}{|c|}{ Texture } \\
\hline Solar cell structure & \multicolumn{4}{|c|}{ n-Si/i-Si/c-Si/BSF } \\
\hline $\begin{array}{l}\text { Exterior rear } \\
\text { reflectance }(\%)\end{array}$ & \multicolumn{4}{|c|}{90} \\
\hline Light source & \multicolumn{4}{|c|}{ One sun (AM 1.5, $\left.100 \mathrm{~mW} / \mathrm{cm}^{2}\right)$} \\
\hline Layer parameter & a-Si:H(n) & a-Si:H(i) & $c-S i(p)$ & Al-BSF \\
\hline Thickness $(\mu \mathrm{m})$ & 0.01 & 0.005 & 250 & 5 \\
\hline Band gap (eV) & 1.92 & 1.7 & 1.12 & 1.12 \\
\hline Dielectric constant & 11.7 & 11.7 & 11.7 & 11.7 \\
\hline Electron affinity $(\mathrm{eV})$ & 3.9 & 3.9 & 4.05 & 4.05 \\
\hline $\begin{array}{l}\text { Electron mobility } \\
\left(\mathrm{cm}^{2} / \mathrm{V}^{-1} \mathrm{~s}^{-1}\right)\end{array}$ & 20 & 20 & 1417 & 200 \\
\hline Hole mobility $\left(\mathrm{cm}^{2} / \mathrm{V}^{-1} \mathrm{~s}^{-1}\right)$ & 10 & 10 & 470 & 80 \\
\hline $\begin{array}{l}\text { Doping concentration } \\
\left(\mathrm{cm}^{-3}\right)\end{array}$ & $1 \times 10^{19}$ & $1 \times 10^{19}$ & $1 \times 10^{16}$ & $1 \times 10^{19}$ \\
\hline Hydrogen content (\%) & - & $0-18$ & - & - \\
\hline
\end{tabular}

The physical models that we used were Shockley-Read-Hall recombination model and concentration-dependent lifetimes. The photogeneration model including a ray tracing algorithm was used for calculating the transmission and absorption of incident light in the semiconductor layers. The solar cells considered here operate under the global standard solar spectrum (AM1.5G) illumination with $100 \mathrm{~mW} / \mathrm{cm}^{2}$ total incident power density. The model structure was (n) a-Si:H/(i) a-Si:H/(p) c-Si/aluminum back surface field (AlBSF). For the individual layer and the a-Si:H/c-Si interfaces, the distributions of defect states are specified. Note that for a$\mathrm{Si}: H$-related materials, the correct material parameters could be varied subject to their preparation conditions. Table 1 summarizes the main parameters used for calculation including measured and assumed values which can be found elsewhere [13-16]. The correlation between the i-layer hydrogen content and performance indicators of solar cells is calculated.

For HJ solar cell fabrication, the cell structure was $\mathrm{Al} /$ indium tin oxide (ITO)/(n) a-Si/(i) a-Si/(p) c-Si/Al-BSF. The boron-doped c-Si wafers with thickness of $250 \mathrm{~nm}$, resistivity of 1-10 $\Omega \mathrm{cm}$, and surface texturization were used as a substrate. The sample size was $156 \times 156 \mathrm{~mm}^{2}$. To form the Al-BSF, a $5 \mu \mathrm{m}$ Al film was sputtered on the wafer backside followed by annealing at $800^{\circ} \mathrm{C}$ for $30 \mathrm{~s}$. The deposition of the $\mathrm{n}$-type a-Si:H was done in a PECVD system with the following process parameters: plasma frequency of $27.12 \mathrm{MHz}$, power density of $37.5 \mathrm{~mW} / \mathrm{cm}^{2}$, substrate temperature of $200^{\circ} \mathrm{C}$, deposition pressure of $90 \mathrm{~Pa}, \mathrm{SiH}_{4}$ flow rate of $40 \mathrm{sccm}$, and total gases flow rate $\left(\mathrm{PH}_{3}+\mathrm{SiH}_{4}+\mathrm{H}_{2}\right)$ of $125 \mathrm{sccm}$. The i-layers with low- and high-hydrogen content were prepared using hydrogen dilution ratios, $\mathrm{H}_{2} / \mathrm{SiH}_{4}$, of 0 and 8 , respectively. Detailed parameters for the $\mathrm{i}-\mathrm{a}-\mathrm{Si}: \mathrm{H}$ layers are summarised in Table 2. The thicknesses of n-layer and i-layer were $10 \mathrm{~nm}$ and $5 \mathrm{~nm}$, respectively. The ITO with
TABle 2: Deposition conditions of low-H and high-H.

\begin{tabular}{lcc}
\hline \multirow{2}{*}{ Parameter } & \multicolumn{2}{c}{ Value } \\
& Low-H & High-H \\
\hline Power density $\left(\mathrm{mW} / \mathrm{cm}^{2}\right)$ & 25 & 25 \\
Pressure $(\mathrm{Pa})$ & 90 & 90 \\
Electrode-to-substrate distance $(\mathrm{mm})$ & 30 & 30 \\
Substrate temperature $\left({ }^{\circ} \mathrm{C}\right)$ & 180 & 180 \\
$\mathrm{SiH}_{4}$ flow rate $(\mathrm{sccm})$ & 40 & 40 \\
$\mathrm{H}_{2}$ flow rate $(\mathrm{sccm})$ & 0 & 320 \\
Hydrogen content $(\%)$ & 6 & 18 \\
\hline
\end{tabular}

thickness of $90 \mathrm{~nm}$ was formed using sputtering to enhance the lateral conductivity and minimize reflection losses. For i-a-Si:H film properties, Fourier transform infrared (FTIR) spectroscopy was used to determine hydrogen content in the films. The hydrogen content $\left(C_{\mathrm{H}}\right)$ was calculated from the integrated intensity of the $\mathrm{Si}-\mathrm{H}$ rocking/wagging mode at $640 \mathrm{~cm}^{-1}$ in the FTIR spectra using the following formula [17]:

$$
C_{\mathrm{H}}=\frac{A_{\omega}}{N_{\mathrm{Si}}} \int_{\omega_{r / \omega}} \frac{\alpha(\omega)}{\omega} d \omega
$$

where $\alpha(\omega)$ is the absorption coefficient of the film at the wavenumber $\omega, \omega_{r / w}$ stands for the rocking/wagging bands around $640 \mathrm{~cm}^{-1} \cdot A_{\omega}=1.6 \times 10^{19} \mathrm{~cm}^{-2}$ is the proportionality constant and $N_{\mathrm{Si}}=5 \times 10^{22} \mathrm{~cm}^{-3}$ is the atomic density of pure silicon. The film thickness was evaluated by an alphastep profiler (Tencor, alpha-step 500). For HJ solar cells, J-V characteristics were measured under AM1.5G (1 sun, $100 \mathrm{~mW} / \mathrm{cm}^{2}$ ) solar simulator irradiation. External quantum efficiencies (EQE) were measured using a lock-in amplifier with a current preamplifier under short-circuit conditions. The devices were illuminated by monochromatic light from a $150 \mathrm{~W}$ xenon lamp passing through a monochromator. A calibrated single crystalline silicon photodiode with known spectral response was used as a reference. The cross-sectional microstructure image was observed by high-resolution transmission electron microscopy (HRTEM). For plasma characterization, optical emission spectroscopy (OES) [18, 19] equipped with a spectra colorimeter was used to collect optical emission spectra of the plasma glowed. The measuring point was near the substrate surface.

\section{Results and Discussion}

Figure 1 schematically shows the mechanism of passivation of dangling bonds at c-Si surface. Without surface passivation, the dangling bonds act as recombination centers to trap electrons, resulting in a large recombination rate at the a-Si:H/c$\mathrm{Si}$ interface of final $\mathrm{HJ}$ solar cells. These dangling bonds can be passivated by $\mathrm{H}$ atoms to obtain a relatively high-quality heterojunction. This in turn implies that $\mathrm{H}$ content in the $\mathrm{i}$-a$\mathrm{Si}: \mathrm{H}$ layer plays a crucial role on the c-Si surface passivation for $\mathrm{HJ}$ solar cells. In this study the $\mathrm{H}$ content in the i-layer is controlled by adjusting the input hydrogen gas flow rate, and their relationship is shown in Figure 1(b). It can be seen that 


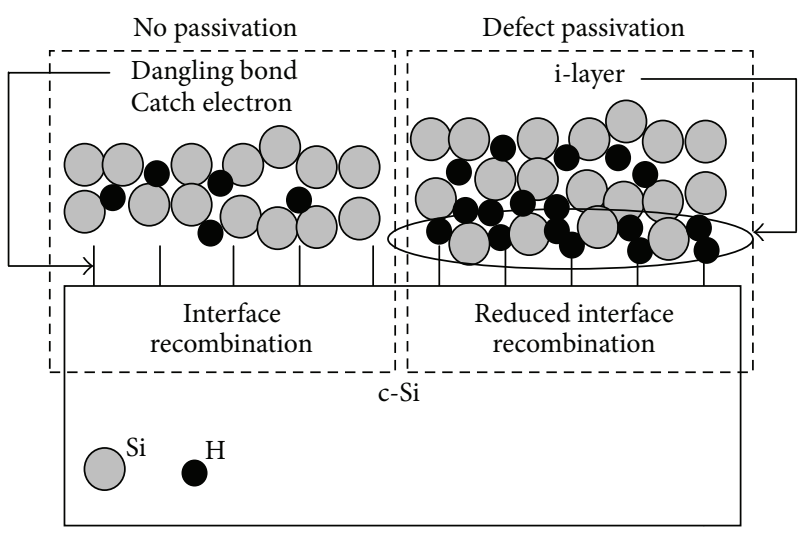

(a)

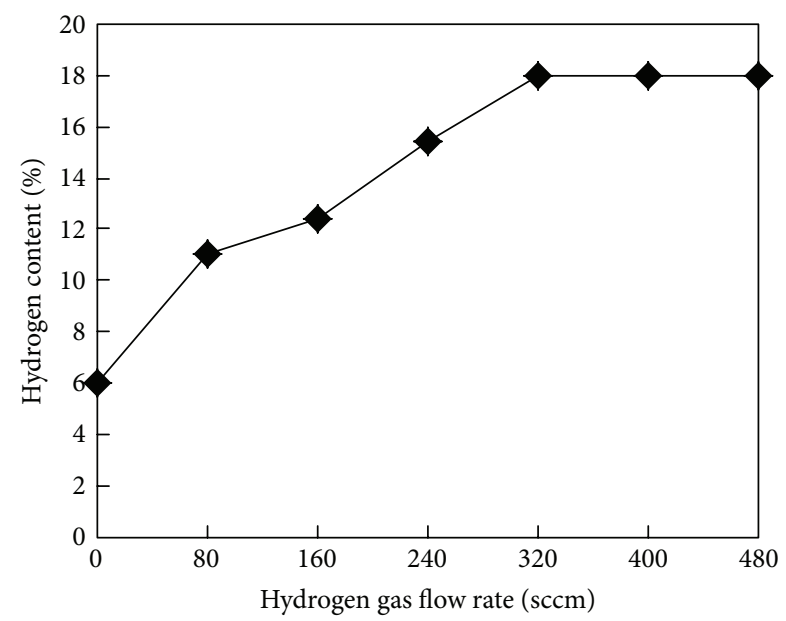

(b)

FIGURE 1: (a) Scheme of the mechanism of surface passivation on c-Si. (b) The relationship between hydrogen flow rate and i-layer hydrogen content.

the hydrogen content increases with increasing the hydrogen gas flow rate due to more $\mathrm{H}$ atoms incorporated in the i-layer during the deposition process. However, the $\mathrm{H}$ content finally saturates to a value of about $18 \%$ at the hydrogen flow rate of $320 \mathrm{sccm}$. According to this result, in TCAD simulation the $\mathrm{H}$ content is set to be in the range of $0-18 \%$ to investigate its effect on the device performances.

Figure 2 shows the TCAD simulation result of the device external parameters such as open-circuit voltage $\left(V_{\text {oc }}\right)$, shortcircuit current density $\left(J_{\mathrm{sc}}\right)$, fill factor $(\mathrm{FF})$, and conversion efficiency $(\eta)$ as a function of the $\mathrm{H}$ content in the i-layer. It can be seen that $V_{\text {oc }}$ show a strong dependence on the ilayer $\mathrm{H}$ content. The pure $\mathrm{i}-\mathrm{a}-\mathrm{Si}(\mathrm{H}$ content $=0 \%)$ leads to $V_{\text {oc }}$ of $0.55 \mathrm{~V}$, while the $\mathrm{i}-\mathrm{a}-\mathrm{Si}: \mathrm{H}$ with $\mathrm{H}$ content of $6 \%-12 \%$ results in $V_{\mathrm{oc}}$ around $0.6 \mathrm{~V}$. Increasing the $\mathrm{H}$ content up to $18 \%$ further improves the $V_{\text {oc }}$ to $0.72 \mathrm{~V}$. The better a-Si:H/c$\mathrm{Si}$ interface passivation with an increase in i-layer $\mathrm{H}$ content could decrease the interface defect (dangling bond) density and recombination for carriers that overcome the a-Si:H/c$\mathrm{Si}$ barrier, and thus could be the reason for the increase in $V_{\text {oc }}$ with an increase in i-layer $\mathrm{H}$ content [20]. $J_{\text {sc }}$ and FF also
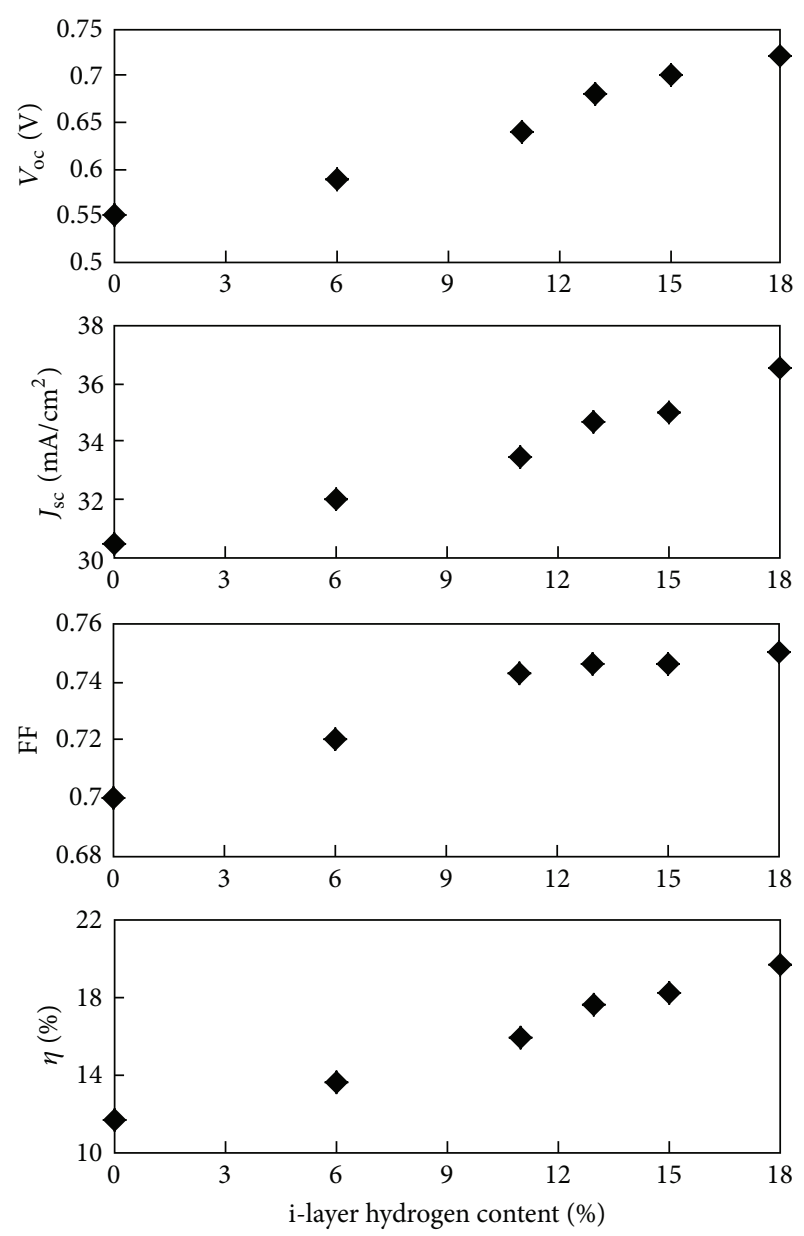

FIGURE 2: Simulation results of the performances of $\mathrm{HJ}$ solar cells as a function of the i-layer hydrogen content.

show a similar tendency to that of $V_{\text {oc }}$. Consequently, $\eta$ can be significantly improved from about $11.7 \%$ to $19.7 \%$ when the $\mathrm{H}$ content increases from $0 \%$ to $18 \%$. It is worth pointing out that high-H content i-layer leads to high-cell performances, which agrees well with the proposed mechanism of passivation mentioned above.

To validate the simulation result, experimental tests were carried out. The i-layers with low- $\mathrm{H}$ content of $6 \%$ and high$\mathrm{H}$ content of $18 \%$ were selected for device fabrication. For each type of i-layer, $10 \mathrm{HJ}$ solar cells were fabricated and their performances are quite close to each other with an error of less than 3\%. Figure 3(a) illustrates the J-V characteristics of the two types of $\mathrm{HJ}$ solar cells. It is observed that the tendency of the experimental result is in good agreement with the simulation data. The high-H cell has better conversion efficiency indicating an improved surface passivation. As compared to the low- $\mathrm{H}$ cell, $V_{\mathrm{oc}}, J_{\mathrm{sc}}$, and $\mathrm{FF}$ are improved by $12.1 \%, 9.3 \%$, and $9.4 \%$, respectively. This consequently leads to an increase in $\eta$ by about $34.2 \%$. Note that FF values are slightly lower than the corresponding simulation values since the resistances of Al, ITO, and their interface are not taken into account in the simulation work. 


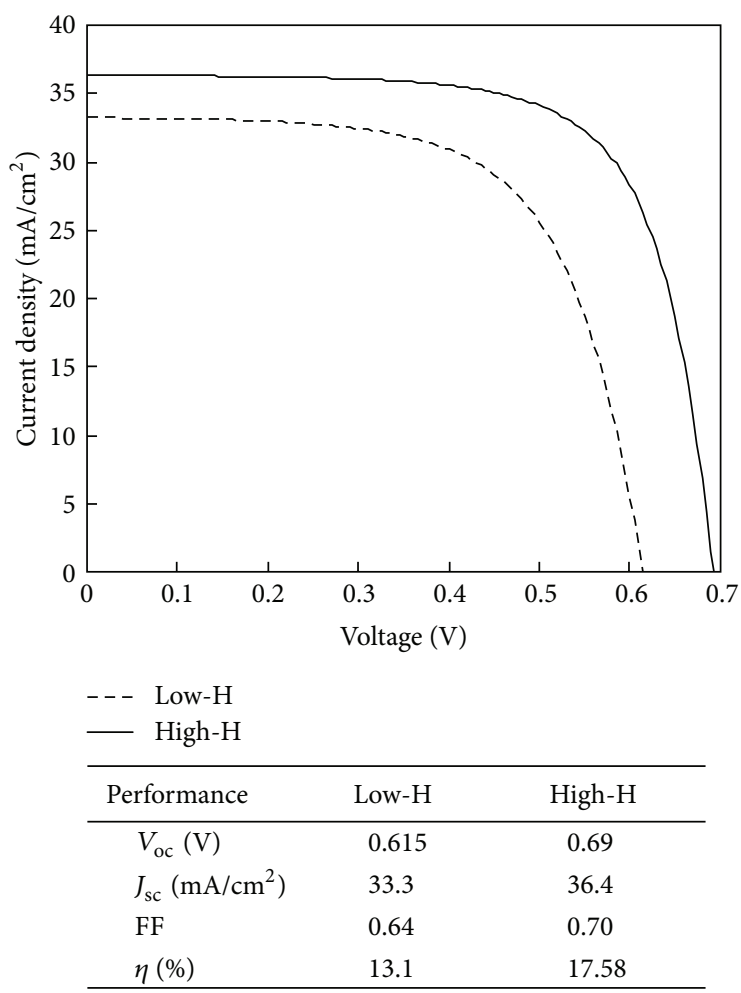

(a)

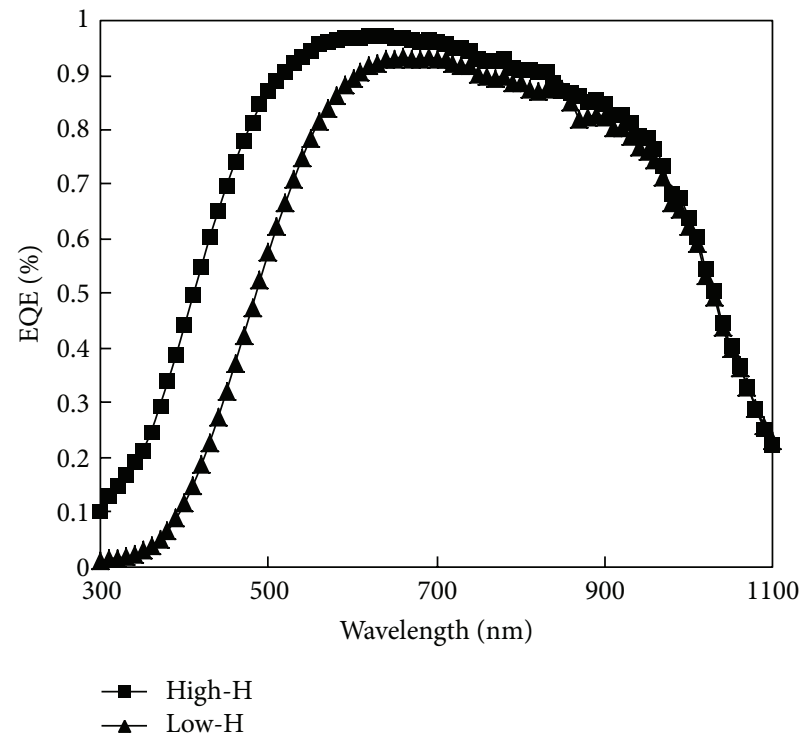

(b)

FIGURE 3: Experimental results of (a) J-V characteristics and (b) EQE spectra response for HJ solar cells with different i-layer hydrogen content.

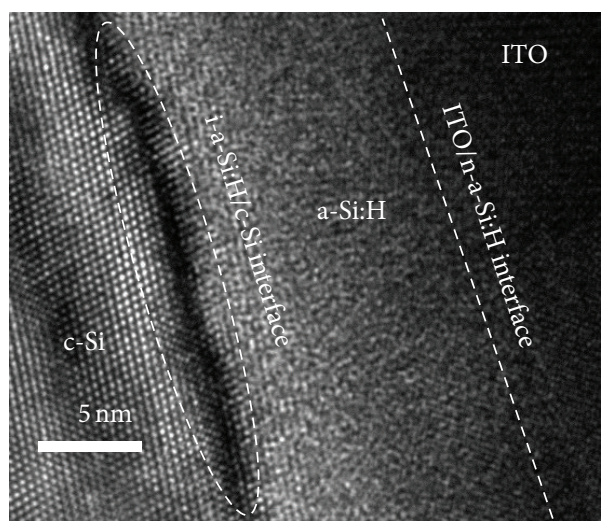

(a)

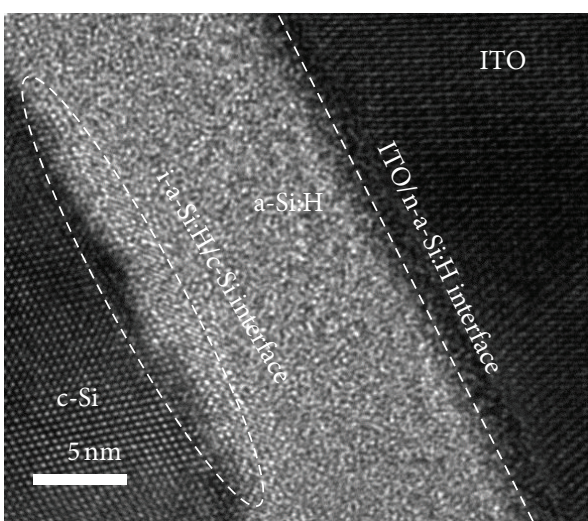

(b)

FiguRE 4: HRTEM images of the i-a-Si:H/p c-Si interface for (a) low-H and (b) high-H HJ solar cells.

The $J_{\text {sc }}$ of the fabricated low- and high-H solar cells can be investigated by EQE measurement as shown in Figure 3(b). Clearly, the EQE response can be divided into two wavelength regions. First, in the wavelength range of 300 to $700 \mathrm{~nm}, \mathrm{EQE}$ values of the high-H cell are always higher than these of the low-H cell. Since blue light is absorbed close to the surface, the higher blue portion of EQE reflects a lower surface recombination and thus reflect better collection efficiency of minority carriers. Note that although the absorption of the two a-Si:H layers possibly may not be the same, the absorption loss due to very thin a-Si:H is trivial and is not one of the factors causing the observed EQE difference. Second, in the wavelength range of 700 to $1100 \mathrm{~nm}$, the EQE values of the two cells become similar, since the light absorption depth in this wavelength range corresponds to deeper region in $\mathrm{c}-\mathrm{Si}$ and thus irrelevant to the junction properties. The EQE at the wavelength of $1100 \mathrm{~nm} \mathrm{[21],} \mathrm{close} \mathrm{to} \mathrm{the} \mathrm{cut-}$ off wavelength, is still over $20 \%$ owing to contributions of surface texturing and back surface field [22]. In summary the EQE result indicates that the higher $J_{\mathrm{sc}}$ of the high-H 


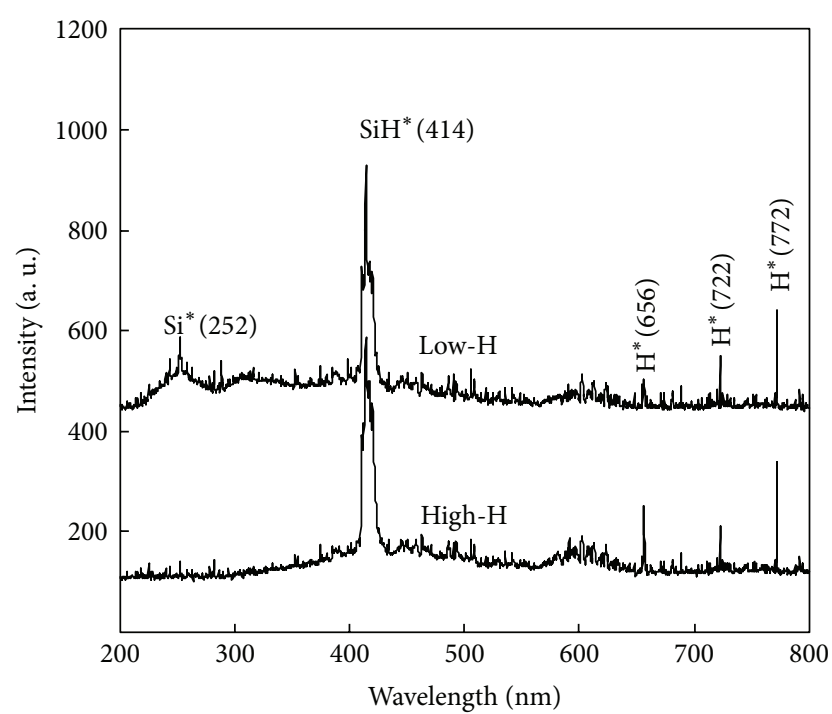

FIGURE 5: Optical emission spectra for the plasmas during low- and high-H i-layer deposition.

cells, as observed in Figure 3(a), is a consequence of the much higher spectral response in the short wavelengths due to better surface passivation.

The cross-sectional HRTEM images of a-Si:H/c-Si interface in low- and high-H cells are shown in Figures 4(a) and 4(b), respectively. The a-Si:H layer (including i- and n-layer) thickness of about $15 \mathrm{~nm}$ can also be evidenced by the TEM images. Interestingly, the low- $\mathrm{H}$ interface is deteriorated, whereas the interface region in the high- $\mathrm{H}$ case is quite smooth. The poor interface region can be assumed to mainly result from two factors. First, it is likely that the interface region contains voids or vacancies related to unpassivated dangling bonds on c-Si surface, illustrated in Figure 1(a), or from $\mathrm{SiH}_{2}$ bonds clustered in the i-layer [23]. Second, it seems that particles occur around the interface, and this phenomenon can be linked to plasma gas particle formation to $\mathrm{c}$-Si substrate interaction. The assumptions are further discussed and explained below using the OES spectra from the plasma point of view.

Figure 5 compares the OES spectra between plasmas during i-layer deposition of low- and high-H solar cells. The peaks shown in the spectra result from several collision of energetic electrons with gas molecules involving the formation of neutral $\left(\mathrm{SiH}_{3}, \mathrm{SiH}_{2}, \mathrm{SiH}, \mathrm{Si}\right)$, emissive $\left(\mathrm{Si}^{*}, \mathrm{SiH}^{*}\right)$, and ionic $\left(\mathrm{SiH}_{x}{ }^{+}\right)$species, as given by $[24,25]$

$$
\begin{aligned}
& \mathrm{SiH}_{4}+\mathrm{e} \\
& \longrightarrow \mathrm{SiH}_{3}+\mathrm{H}+\mathrm{e}(4.0 \mathrm{eV} ; \tau>20 \mathrm{~ms}) \\
& \longrightarrow \mathrm{SiH}_{2}+\mathrm{H}_{2}+\mathrm{e}(2.2 \mathrm{eV} ; \tau<3 \mathrm{~ms}) \\
& \longrightarrow \mathrm{SiH}+\mathrm{H}_{2}+\mathrm{H}+\mathrm{e}(5.7 \mathrm{eV} ; \tau<3 \mathrm{~ms}) \\
& \longrightarrow \mathrm{Si}+2 \mathrm{H}_{2}+\mathrm{e}(4.2 \mathrm{eV} ; \tau<3 \mathrm{~ms}) \\
& \mathrm{SiH}_{2} \longrightarrow \mathrm{Si}^{*}+\mathrm{H}_{2}
\end{aligned}
$$

$$
\begin{gathered}
\mathrm{Si}^{*} \longrightarrow \mathrm{Si}+h \nu(4.9-5.1 \mathrm{eV}) \\
\mathrm{SiH}_{3} \longrightarrow \mathrm{SiH}^{*}+\mathrm{H}_{2} \\
\mathrm{SiH}^{*} \longrightarrow \mathrm{SiH}+h \nu(3 \mathrm{eV})
\end{gathered}
$$

where e is the electron, $h v$ is the released photon energy, and $\tau$ is the life time of the Si-based radicals. Among the various radicals, $\mathrm{SiH}_{2}$-related reactions described in (3), and (4) finally release a photon energy from $\mathrm{Si}^{*}$ radiative decay corresponding to a wavelength of $252 \mathrm{~nm}$. Interestingly, this released photon is detected by OES only in the plasma for the low-H cell, while this peak vanishes for the high-H cell. Thus, the plasma in low-H i-layer deposition contains a much larger amount of $\mathrm{SiH}_{2}$, finally leading to void-rich and low-quality i-layer [26, 27]. In addition, another effect accompanied with high $\mathrm{SiH}_{2}$ amount is the increased generation rate of poly silane (gas particle formation), $\mathrm{Si}_{2} \mathrm{H}_{6}$, according to [28]

$$
\mathrm{SiH}_{2}+\mathrm{SiH}_{4} \longrightarrow \mathrm{Si}_{2} \mathrm{H}_{6}
$$

The resultant $\mathrm{Si}_{2} \mathrm{H}_{6}$ species will interfere with film deposition and thus lead to a poor interface. Therefore, the OES spectra confirm the assumptions as mentioned in Figure 4. On the contrary, the Si-related peak found in the spectra of the high$\mathrm{H}$ cell is only $\mathrm{SiH}^{*}$ at $414 \mathrm{~nm}$ (see (5) and (6)), and thus the increased proportion of $\mathrm{SiH}_{3}$ is beneficial to the film growth with high qualities [29] leading to a smooth interface shown in Figure 4(b).

\section{Conclusions}

In this study, the effect of a-Si:H i-layer hydrogen content of $0-18 \%$ on performances of $\mathrm{HJ}$ solar cells is investigated. Both of the experimental and simulation results indicate that the i-layer with high-hydrogen content can lead to a higher degree of dangling bond passivation on c-Si surface. Compared to low-H i-layer, $\mathrm{HJ}$ solar cells with a high-H ilayer is found to have the i-layer/c-Si interface with reduced surface recombination and increased collection efficiency for blue light generated carriers. In addition to surface dangling bond passivation, the low-H solar cell exhibits a deteriorate i-layer/c-Si interface. The OES spectra clearly show the presence of $\mathrm{Si}^{*}$ peak only found in the plasma of low-H i-layer deposition suggesting that the large $\mathrm{SiH}_{2}$ portion may finally create voids and Si particles and thus decrease the i-layer/c-Si interface quality.

\section{Acknowledgment}

This work was supported by the National Science Council (102-2622-E-451-002-CC3, 102-2622-E-451-001-CC2, and 100-2628-E-451-002-MY2).

\section{References}

[1] Y. Tsunomura, Y. Yoshimine, M. Taguchi et al., "Twenty-two percent efficiency HIT solar cell," Solar Energy Materials and Solar Cells, vol. 93, no. 6-7, pp. 670-673, 2009. 
[2] T. Mishima, M. Taguchi, H. Sakata, and E. Maruyama, "Development status of high-efficiency HIT solar cells," Solar Energy Materials and Solar Cells, vol. 95, no. 1, pp. 18-21, 2011.

[3] T. Kinoshita, D. Fujishima, A. Yano et al., "The approaches for high efficiency HITTM solar cell with very thin $(<100 \mu \mathrm{m})$ silicon wafer over 23\%," in Proceedings of the 26th European Photovoltaic Solar Energy Conference and Exhibition, pp. 871874, Hamburg, Germany, 2011.

[4] K. V. Maydell, H. Windgassen, W. A. Nositschka et al., "Basic electronic properties and technology of TCO/a-Si:H(n)/c-Si(p) heterostructure solar cells: a german network project," in Proceedings of the 20th European Photovoltaic Solar Energy Conference and Exhibition, p. 822, Barcelona, Spain, 2005.

[5] H. Fujiwara and M. Kondo, "Effects of a-Si:H layer thicknesses on the performance of a-Si:H/c-Si heterojunction solar cells," Journal of Applied Physics, vol. 101, Article ID 054516, 2007.

[6] T. H. Wang, E. Iwaniczko, M. R. Page et al., "Effective interfaces in silicon heterojunction solar cells," in Proceedings of the 31st IEEE Photovoltaic Specialists Conference and Exhibition, pp. 955-958, Orlando, Fla, USA, January 2005.

[7] V. A. Dao, N. V. Duy, J. Heo et al., "Hydrogenated amorphous silicon layer formation by inductively coupled plasma chemical vapor deposition and its application for surface passivation of p-type crystalline silicon," Japanese Journal of Applied Physics, vol. 48, no. 6, Article ID 066509, 2009.

[8] N. Dwivedi, S. Kumar, A. Bisht, K. Patel, and S. Sudhakar, "Simulation approach for optimization of device structure and thickness of HIT solar cells to achieve $27 \%$ efficiency," Solar Energy, vol. 88, pp. 31-41, 2013.

[9] N. Hernández-Como, A. Morales-Acevedo, and Y. Matsumoto, "I-V characteristics of a-Si-c-Si hetero-junction diodes made by hot wire CVD," Solar Energy Materials and Solar Cells, vol. 95, no. 8, pp. 1996-2000, 2011.

[10] A. Matsuda, M. Takai, T. Nishimoto, and M. Kondo, "Control of plasma chemistry for preparing highly stabilized amorphous silicon at high growth rate," Solar Energy Materials and Solar Cells, vol. 78, no. 1-4, pp. 3-26, 2003.

[11] W. M. M. Kessels, R. J. Severens, A. H. M. Smets et al., "Hydrogenated amorphous silicon deposited at very high growth rates by an expanding $\mathrm{Ar}-\mathrm{H}_{2}-\mathrm{SiH}_{4}$ plasma," Journal of Applied Physics, vol. 89, no. 4, pp. 2404-2413, 2001.

[12] J. Gea, Z. P. Linga, J. Wonga, T. Muellera, and A. G. Aberlea, "Optimisation of intrinsic a-Si:H passivation layers in crystalline-amorphous silicon heterojunction solar cells," Energy Procedia, vol. 15, pp. 107-117, 2012.

[13] L. Zhao, H. L. Li, C. L. Zhou, H. W. Diao, and W. J. Wang, "Optimized resistivity of p-type Si substrate for HIT solar cell with $\mathrm{Al}$ back surface field by computer simulation," Solar Energy, vol. 83, no. 6, pp. 812-816, 2009.

[14] A. Datta, M. Rahmouni, M. Nath, R. Boubekri, P. R. Cabarrocas, and P. Chatterjee, "Insights gained from computer modeling of heterojunction with instrinsic thin layer "hIT" solar cells," Solar Energy Materials and Solar Cells, vol. 94, no. 9, pp. 1457-1462, 2010.

[15] L. Zhao, C. L. Zhou, H. L. Li, H. W. Diao, and W. J. Wang, "Design optimization of bifacial HIT solar cells on p-type silicon substrates by simulation," Solar Energy Materials and Solar Cells, vol. 92, no. 6, pp. 673-681, 2008.

[16] V. A. Dao, J. Heo, H. Choi et al., "Simulation and study of the influence of the buffer intrinsic layer, back-surface field, densities of interface defects, resistivity of p-type silicon substrate and transparent conductive oxide on heterojunction with intrinsic thin-layer (HIT) solar cell," Solar Energy, vol. 84, no. 5, pp. 777$783,2010$.

[17] J. Gopea, S. Kumar, S. Sudhakar, K. Lodhi, C. M. S. Rauthana, and P. C. Srivastava, "Influence of argon dilution on the growth of amorphous to ultra nanocrystalline silicon films using VHF PECVD process," Journal of Alloys and Compounds, vol. 577, pp. 710-716, 2013.

[18] A. A. Howling, B. Strahm, P. Colsters, L. Sansonnens, and C. Hollenstein, "Fast equilibration of silane/hydrogen plasmas in large area RF capacitive reactors monitored by optical emission spectroscopy," Plasma Sources Science and Technology, vol. 16, no. 4, pp. 679-696, 2007.

[19] A. A. Howling, B. Strahm, and C. Hollenstein, "Non-intrusive plasma diagnostics for the deposition of large area thin film silicon," Thin Solid Films, vol. 517, no. 23, pp. 6218-6224, 2009.

[20] N. Hernández-Como and A. Morales-Acevedo, "Simulation of hetero-junction silicon solar cells with AMPS-1D," Solar Energy Materials and Solar Cells, vol. 94, no. 1, pp. 62-67, 2010.

[21] M. Schaper, J. Schmidt, H. Plagwitz, and R. Brendel, "20.1\%efficient crystalline silicon solar cell with amorphous silicon rear-surface passivation," Progress in Photovoltaics: Research and Applications, vol. 13, no. 5, pp. 381-386, 2005.

[22] L. Zhao, H. L. Li, C. L. Zhou, H. W. Diao, and W. J. Wang, "Optimized resistivity of p-type Si substrate for HIT solar cell with Al back surface field by computer simulation," Solar Energy, vol. 83, no. 6, pp. 812-816, 2009.

[23] D.-S. Wuu, S.-Y. Lien, H.-Y. Mao et al., "Growth and characterization of polycrystalline Si films prepared by hot-wire chemical vapor deposition," Thin Solid Films, vol. 498, no. 1-2, pp. 9-13, 2006.

[24] J. C. Knights, "Characterization of plasma-deposited amorphous Si: H thin films," Japanese Journal of Applied Physics, vol. 18, pp. 101-108, 1979.

[25] F. J. Kampas, "Reactions of atomic hydrogen in the deposition of hydrogenated amorphous silicon by glow discharge and reactive sputtering," Journal of Applied Physics, vol. 53, no. 9, pp. 64086412, 1982.

[26] H.-Y. Kim, K.-Y. Lee, and J.-Y. Lee, “The influence of hydrogen dilution ratio on the crystallization of hydrogenated amorphous silicon films prepared by plasma-enhanced chemical vapor deposition," Thin Solid Films, vol. 302, no. 1-2, pp. 17-24, 1997.

[27] M. Jeon, S. Yoshiba, and K. Kamisako, "Hydrogenated amorphous silicon film as intrinsic passivation layer deposited at various temperatures using RF remote-PECVD technique," Current Applied Physics, vol. 10, no. 2, pp. S237-S240, 2010.

[28] A. Matsuda, "Control of plasma and surface conditions for low defect density a-Si:H at high growth rates," in Proceedings of the 25th IEEE Photovoltaic Specialists Conference, pp. 1029-1034, May 1996.

[29] W. M. M. Kessels, J. P. M. Hoefnagels, P. J. van den Oever, Y. Barrell, and M. C. M. van de Sanden, "Temperature dependence of the surface reactivity of $\mathrm{SiH}_{3}$ radicals and the surface silicon hydride composition during amorphous silicon growth," Surface Science, vol. 547, no. 3, pp. L865-L870, 2003. 

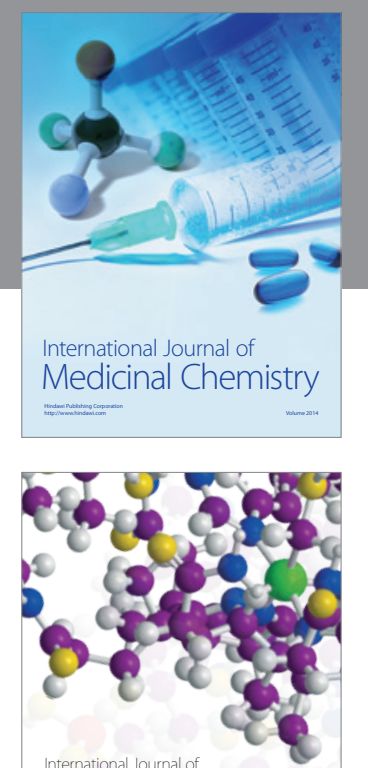

\section{Carbohydrate} Chemistry

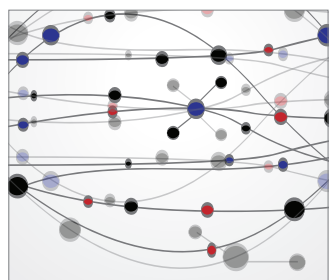

The Scientific World Journal
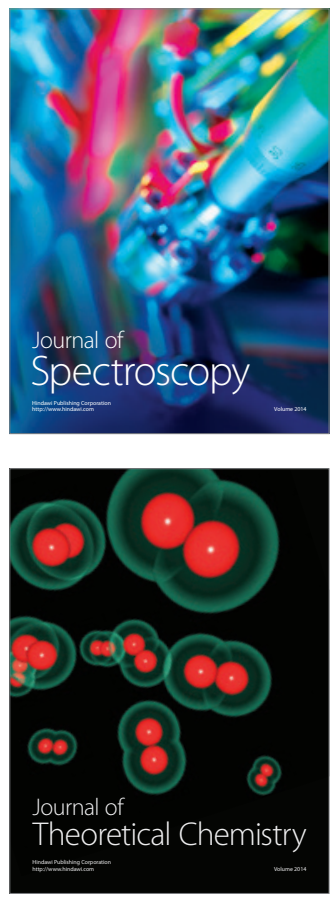
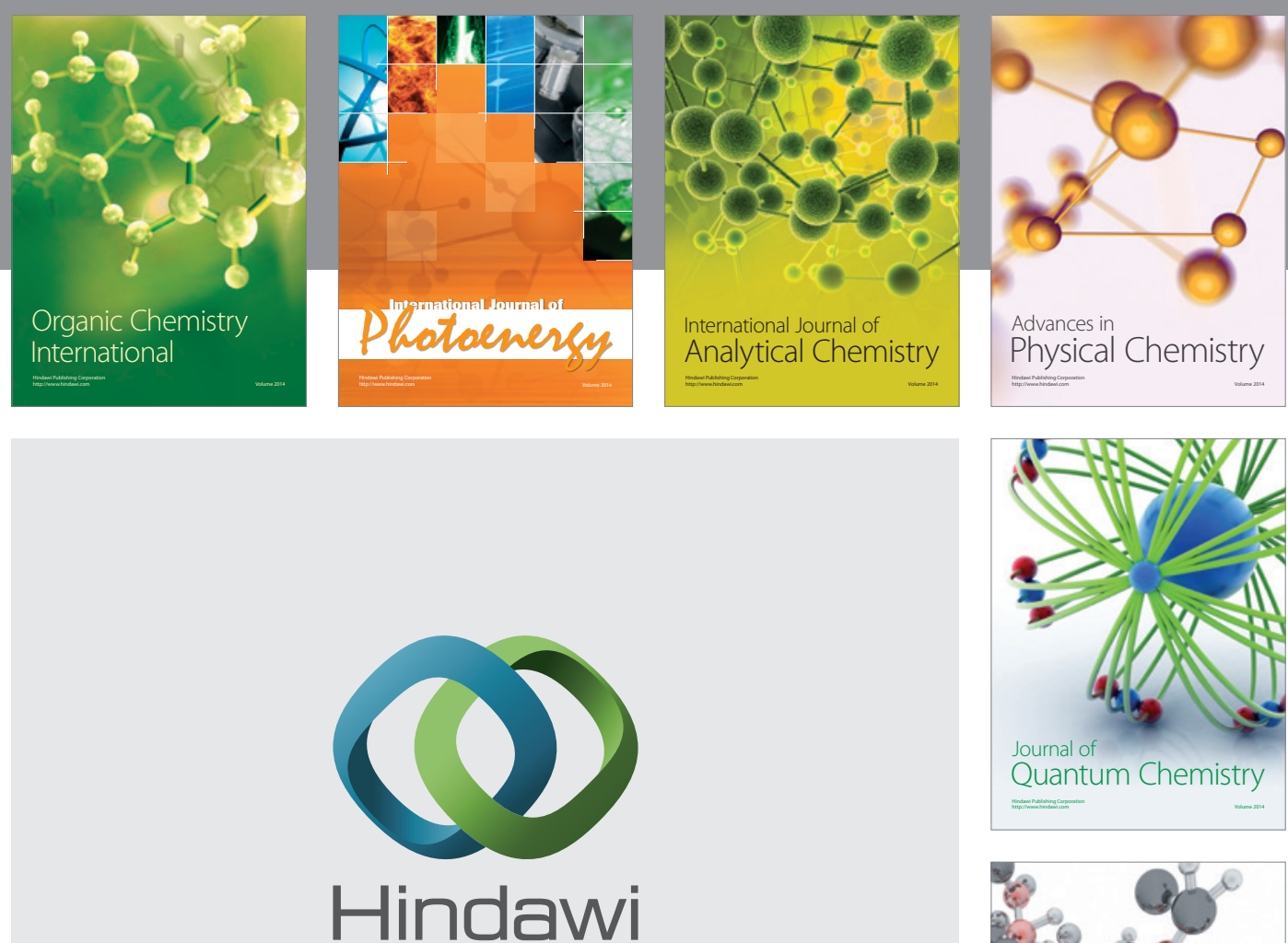

Submit your manuscripts at

http://www.hindawi.com

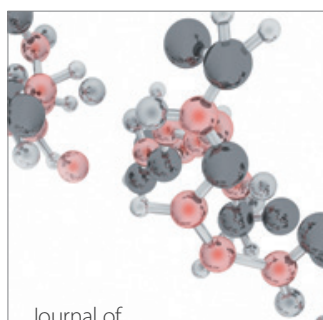

Analytical Methods

in Chemistry

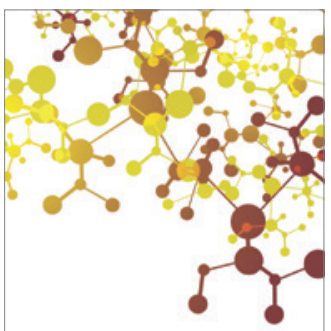

Journal of

Applied Chemistry

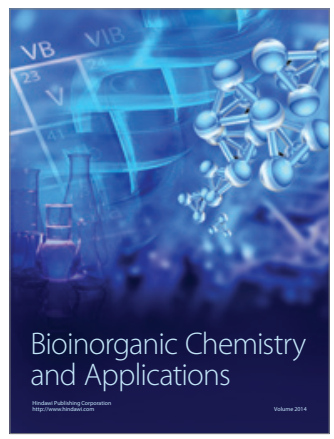

Inorganic Chemistry
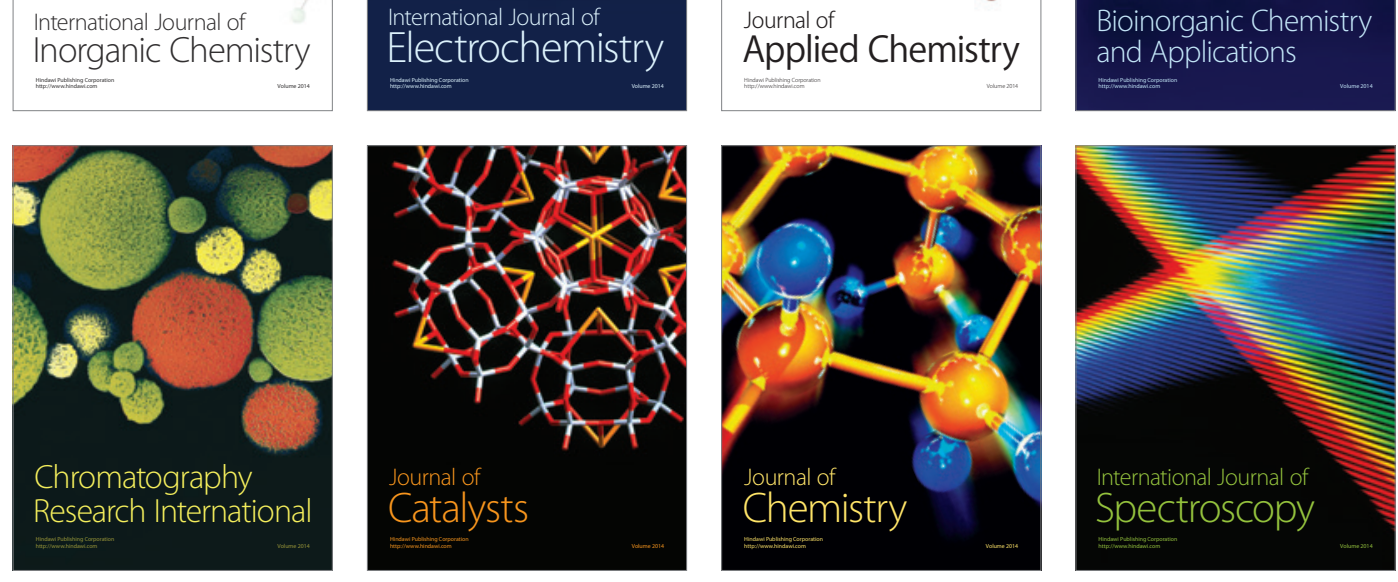